\title{
The rise of non-dissertation track master's programmes: an academic literacies approach
}

Article

Accepted Version

Hasrati, M. and Tavakoli, P. (2019) The rise of non-dissertation track master's programmes: an academic literacies approach. Innovations in Education and Teaching International, 56 (5). pp. 639-651. ISSN 1470-3297 doi:

https://doi.org/10.1080/14703297.2019.1570304 Available at https://centaur.reading.ac.uk/80874/

It is advisable to refer to the publisher's version if you intend to cite from the work. See Guidance on citing.

To link to this article DOI: http://dx.doi.org/10.1080/14703297.2019.1570304

Publisher: Taylor \& Francis

All outputs in CentAUR are protected by Intellectual Property Rights law, including copyright law. Copyright and IPR is retained by the creators or other copyright holders. Terms and conditions for use of this material are defined in the End User Agreement.

www.reading.ac.uk/centaur 
Central Archive at the University of Reading

Reading's research outputs online 
The Rise of Non-Dissertation Track Master's Programmes: An Academic Literacies Approach

Hasrati, M. \& Tavakoli, P. (2019). The Rise of Non-Dissertation Track Master's Programmes: An Academic Literacies Approach. Innovations in Education and Teaching International; Taylor and Francis.

\begin{abstract}
Although dissertations have traditionally been part of master's programmes, non-dissertation track master's are on the rise across the world. This paper reports faculty views on MA TESOL dissertations (Teaching English to Speakers of Other Languages) in five Anglophone countries. Drawing on the academic literacies tradition and informed by Bourdieusian concepts of 'field', 'habitus', and 'symbolic violence', the results suggest that the need for more student intake has affected the presence or absence of the dissertation component in MA TESOL programmes.
\end{abstract}

Keywords: MA TESOL dissertations; academic literacies; habitus; field

\title{
Introduction
}

While the MA TESOL dissertation is often indispensable in the UK (Hasrati \& Tavakoli, 2015), non-dissertation master's programmes seem to be gaining popularity in other parts of the world, and a quick online search reveals that many universities are now promoting such programmes. Master's dissertations are important areas of research for three main reasons. First, dissertations are considered important disciplinary literacy practices, and therefore a well-written dissertation highlights the degree of students' mastery of these practices. Secondly, given the central role of writing in academic achievement, especially in contexts such as the UK, dissertation writing is 
regarded as a key means of learning. Finally, a master's dissertation is considered a training exercise for the more substantial $\mathrm{PhD}$ thesis. Despite such significance, little research has been conducted to examine the importance of master's dissertations from key stakeholders' perspectives. Given the spread of non-dissertation master's programmes, it is necessary to understand the contextual factors surrounding such programmes in different educational contexts. The current paper reports the results of a study of non-dissertation master's programmes of TESOL (Teaching English to Speakers of Other Languages) as perceived by faculty in five Anglophone countries, namely the UK, the USA, Canada, Australia and New Zealand. Our focus on TESOL is motivated by our background and observation of the rise of non-dissertation master's in this area. This study, though not exhaustive, helps ascertain this trend and explore the prevalence of such programmes.

\section{Research on dissertation writing}

Although various studies have examined PhD programmes (Nightingale, 1984; Holbrooke et al., 2008; Stracke \& Kumar, 2010; Kiley \& Mullins, 2004; Tinkler \& Jackson, 2000), master’s programmes, and their dissertation component in particular, have relatively been underresearched, which is why most research reported here is on $\mathrm{PhD}$ education. Some researchers have investigated the significance of supervisors in the successful completion of a dissertation (Belcher, 1994; Belcher \& Hirvela, 2005; Dong, 1996; Ohashi, Ohashi, \& Paltridge, 2008; Dysthe, 2002; Lindsay, 2015), while others have studied differences between native and nonnative (NNS) students in dissertation writing (Powers, 1994; Allison et al, 1998). Some have problematised the very definition of dissertation and studied various options available to graduate students (Paltridge, 2002). 
Apart from studies on dissertation as 'text', a growing number of studies have dealt with social, political and material 'contexts' of this literacy practice. Jenkins et al (1993) were among the first to report how some engineering supervisors wrote parts of their students' dissertations to speed up the slow process of dissertation writing by their students whom they paid on research contracts. Similarly, Hasrati (2013a) reported how material and credentialing incentives had boosted the publication record of faculty in an Iranian university (see also Canagarajah, 1996; Casanave, 2003; Lillis \& Curry, 2010; Hasrati, 2013b). In a more recent study, Sinkonvic, Richardson and Lew (2016) demonstrated the perceived usefulness of dissertation writing and argued that dissertations are unique in enhancing students' employability.

\section{MA dissertations as sociopolitical literacy practices}

In order to explore dissertation writing, we employ the academic literacies tradition, an extension of Street's (1984) 'ideological' model of literacy, to explore the rise of non-dissertation master's programmes. This is because this approach regards literacy not as 'autonomous' knowledge residing in the minds of people, but as 'ideological' practices intertwined with culture, society and power (Street, 1984). In his later writings, Street offers the concept of 'academic literacies' to argue there are different varieties of literacies in academia, tied with practices and epistemological stance (also see Barton et al. 2000). The academic literacies tradition goes beyond 'text' by considering the wider social context of text production and use, which is similar to works that inherently link literacy to social and political contexts (e.g. Freire 1970; Freebody and Luke 1990; Gee 2015). Our approach is similar to this line of research as we are cognizant of the societal demands and expectations in literacy practices. 
Another important theoretical framework employed in this study is Bourdieu's (2001) concept of 'symbolic violence', defined as "a gentle violence, imperceptible and invisible even to its victims, exerted for the most part through the purely symbolic channels of communication and cognition" (pp. 1-2). At the core of this concept lies "misrecognition" in which the oppressed social entities recognize their own domination as legitimate (Bourdieu, 1991, p. 140). Misrecognition, in other words, is a "form of forgetting" as the dominated come to believe in the status quo as "natural" and "legitimate"' and, often willingly, partake in the violence being exercised on them (Webb, Schirato, \& Danaher, 2002, p. 24). We assume that 'academic tribes in different territories' (Becher, 1989) often undergo this form of violence by financial and often non-academic aspects of higher education. Our study suggests that the academic literacies tradition should be redefined to include the role of symbolic violence in various academic communities around the globe. We also employ three other Bourdieusian concepts, namely 'cultural capital', 'habitus' and 'field' (Bourdieu, 1991; Grenfell and James, 1998). Cultural capital is the product of education, field the objective social world realities, and habitus the subjective customized versions of those realities. We will further take these up in discussion.

\section{Methodology and results}

The following research questions guided the study: 1) In what ways do the faculty understand and interpret the rise of non-dissertation master's programmes? 2) Are there differences in faculty views about non-dissertation programmes in these contexts? 3) How can the presence or absence of dissertation be understood in the light of the academic literacies tradition informed by Bourdieu's concept of symbolic violence? We sought answers to these questions by collecting data from faculty involved in teaching and supervising masters' dissertations. Given their direct 
responsibility for supervising dissertations, faculty views would best shed light on our questions about the rise of non-dissertation programmes. In addition, faculty are positioned between master's students and policy makers, and can therefore better comment on various aspects of dissertation writing. Nevertheless, we acknowledge that more data from other stakeholders, e.g., students and policy makers, could further unpack issues related to the rise of non-dissertation programmes.

Although we contacted a sizeable number of potential participants and collected a fair amount of data, we do not claim generalizability of our findings. As such, this study is a 'telling case' (Mitchell, 1984, p. 239) where instead of generalizing based on a large number of samples, we are mapping our understanding of data on theoretical frameworks to make sense of them, which illustrates our social constructivist approach to research.

A questionnaire, which was a revised draft from an earlier study (Hasrati \& Tavakoli, 2015) (Appendix 1), was employed to elicit both quantitative and qualitative data, consisting of three main sections: 17 Likert-scale questions, three open-ended questions, and three questions on the experience of the participants. After a pilot with five participants, the questionnaire was sent to faculty engaged in supervising MA TESOL dissertations in 114 different universities in Australia, Canada, New Zealand, the UK and the USA, selected by an online search of universities offering MA TESOL/Applied Linguistics. Our choice of MA TESOL programmes was motivated by our professional identity as TESOL academics, and our focus on these countries by the observation that they are often considered 'developed centre' (Wallerstein, 1974; Canagarajah, 1996), and that they are highly popular destinations for international students pursuing MA TESOL/Applied Linguistics qualifications. 
The respondents were 126 faculty members: 19 in Australia, 21 in Canada, 16 in New Zealand, 34 in the UK, and 36 in the USA. The inclusion criteria were a) working in a department offering any MA TESOL/Applied Linguistics, and b) having at least three years of experience supervising MA dissertations. The demographic data showed that all participants held a $\mathrm{PhD}$ (or equivalent) in an area of Education or Applied Linguistics, indicating a range of research interests and experiences. The project was subject to careful ethical considerations: the questionnaire was anonymous, the data were treated confidentially, and the participants could withdraw from the study at any time.

The qualitative data comprised more than 12,000 words, which were initially coded and categorized through 'open thematic coding' (Glaser, 1992, p. 39; Agar, 1996, p. 153). We read the data individually and prepared a list of codes and their frequencies before we compared our codes with one another. After this initial open thematic coding, we compared and discussed our lists to agree on a set of core codes that could help answer our research questions. For example, a comment such as "Expansion of online programs for MA in TESOL and market driven competition between universities and countries has driven [universities to attract more students]" was initially coded as 'institutional push for more intake'. This was then considered as a subcategory of a core concept coded as 'market-related interest', which was tagged to research question 1.

In this paper, we will base our arguments on the findings from the qualitative analysis, but we will also refer to the frequency analyses of the quantitative data as and when appropriate. A number followed by the reduced form of participants' countries will be used to identify them. For instance, P21UK indicates that the quotation comes from Participant Number 21 based in a UK university. 


\section{Differences across contexts}

A number of key differences were observed between the participants' views in various contexts in terms of the value they perceived in dissertation writing and the rationale for developing non-

dissertation tracks. The most pronounced difference was between the participants in the UK and the USA. While $72.7 \%$ of the US participants believed that the dissertation is not a necessary component in MA programmes, $85.3 \%$ of the UK participants considered it essential. Many UK participants (15 out of 34) had not even heard of such programmes: "I am sorry but I was not even aware of this strand. I know the word limit varies but I do not realise some programmes have dropped the dissertation" (P7UK). In contrast, it seemed that non-dissertation MA TESOL programmes were quite established in US universities: "the MA thesis has always been optional" (P13US).

We interpret the discrepancy between the two views on the importance of dissertation writing in the light of the local academic literacy practices employed in these two contexts, which seemed to be influenced by a global market for overseas students. Employing Bourdieu's concept of 'field' and 'habitus', it seems that a globalized market of students has created a 'global field' where 'institutional habituses' operate across the five countries in the study.

Regardless of disagreement over the necessity of dissertations in MA TESOL programmes, most participants in all five countries believed that dissertations help students learn disciplinary world views and writing conventions (Tables 1 and 2). In contrast with US respondents, the majority of participants in other countries would not accept a non-dissertation graduate to a $\mathrm{PhD}$ program. While almost a third of the US participants sat on the fence, a large 
number of them (44.4\%) would be happy to accept non-dissertation graduates to $\mathrm{PhD}$ programmes (Table 3).

\begin{tabular}{|l|l|l|l|}
\hline Question 5 & Percentage & Agree & Disagree \\
\hline CAN & 76.2 & $\square$ & \\
\hline USA & 57.1 & $\square$ & \\
\hline UK & 84.4 & $\square$ & \\
\hline AUS & 89.5 & $\square$ & \\
\hline NZ & 75 & $\square$ & \\
& & & \\
\hline
\end{tabular}

Table 1: MA dissertations are important in helping students learn disciplinary world views

\begin{tabular}{|l|l|l|l|}
\hline Question 6 & Percentage & Agree & Disagree \\
\hline CAN & 85.8 & $\square$ & \\
\hline USA & 80.6 & $\square$ & \\
\hline UK & 88.3 & $\square$ & \\
\hline AUS & 94.8 & $\square$ & \\
\hline NZ & 93.8 & $\square$ & \\
\hline
\end{tabular}

Table 2: MA dissertations are important in helping students learn disciplinary writing conventions

\begin{tabular}{|l|l|l|l|}
\hline Question 9 & Percentage & Agree & Disagree \\
\hline CAN & 65 & & $\square$ \\
\hline USA & 44.4 & $\square$ & \\
\hline UK & 82.3 & & $\square$ \\
\hline AUS & 94.7 & & $\square$ \\
\hline
\end{tabular}




\begin{tabular}{|l|l|l|l|}
\hline NZ & 56.2 & & $\square$ \\
\hline
\end{tabular}

Table 3: I would have no hesitation accepting a non-dissertation track MA TESOL graduate to a PhD program

\section{The rise of non-dissertation tracks}

\section{Addressing market-related interests}

A set of market related reasons stood out for the popularity of non-dissertation track

programmes. A major reason was the commodification of higher education. Statements such as the following underpin faculty views about the markets' power and influence on higher education: "higher education has been commodified, and I presume it is simply adapting to the market" (P29UK); "the nature of qualification is changing [because] the current environment is market-driven (P17AUS).

This commodification seems to have led to institutional push for larger student intakes, in particular in relation to overseas students: "I think [non-dissertation masters] have been introduced to appease the growing interest in the MA degree and the constant push for more students" (P3CAN). Likewise, another participant commented, "[non-dissertation programmes are becoming more widespread because] of economic pressures within the university to meet international demands for shorter, less demanding academic pathways to the MA qualification" (P5NZ).

It also seemed that institutional resources lagged behind increasing student intakes. More specifically, there was evidence that the current faculty were overwhelmed and could not find enough time to cater for all students, so running non-dissertation programmes, which required less expertise, was attractive to universities: "as more and more demands are placed on faculty time, not requiring a thesis of every student makes sense for all involved. (P27US)". Statements 
like these highlight the complex relationship between a market-oriented higher education and institutional pressure on faculty to develop market friendly and competitive initiatives.

\section{Responding to students' needs}

An important reason for the popularity of non-dissertation programmes seems to be students' differential needs. There are numerous examples in the data to suggest some students need a higher degree for purely professional and employment purposes and do not want to pursue a $\mathrm{PhD}$. One of the participants argued that "MA programs in Applied Linguistics are training language-teaching professionals; this is a professional credential focused on theory- and evidence-based practice, not one whose primary purpose is to prepare students for doctoral work" (P27US). Another participant stated that "there is a growing number of students who consider the MA as a terminal degree; that is focus will be on entering practice and not continuing on to $\mathrm{PhD}$ programmes or conducting research" (P28US). Such statements are indicative of not only the faculty's acknowledgement and appreciation of diversity in students' needs, but their awareness that such diverse needs should be met differently.

\section{Providing a more facilitated pathway}

Non-dissertation programmes are deemed faster, more efficient and "cost-effective for students and delivering institutions" (P5AUS). The quantitative data further proved these findings as most participants believed dissertation track programmes are more suitable for students wishing to continue into a $\mathrm{PhD}$ (Table 4).

\begin{tabular}{|l|l|l|l|}
\hline Question 10 & Percentage & Agree & Disagree \\
\hline CAN & 88.9 & $\square$ & \\
\hline
\end{tabular}




\begin{tabular}{|l|l|l|l|}
\hline USA & 63.9 & $\square$ & \\
\hline UK & 88.2 & $\square$ & \\
\hline AUS & 94.7 & $\square$ & \\
\hline NZ & 93.3 & $\square$ & \\
\hline
\end{tabular}

Table 4: Dissertation-track programmes are more suitable for students who want to continue into a $\mathrm{PhD}$

Other participants even cast doubt on the suitability of dissertation writing in all contexts and for all students: "requiring a thesis as the only option perpetuates the model of self-reproduction that has generally dominated higher education, and that model is no longer appropriate (if it ever was)" (P27US). Such comments appear to represent an underlying belief about the need for academic literacy practices to be malleable to change according to academic contexts, student needs and educational aims.

\section{Discussion and conclusion}

The first research question focused on faculty understanding of the rise of non-dissertation MA TESOL programmes. While emphasizing the benefits of dissertation writing, the participants acknowledged the diversity of students' needs which should be taken into account in curriculum development and programme planning. Clearly, market-driven forces and interests seem to be a major factor in the rise of non-dissertation MA programmes, leading to a hierarchical 'symbolic violence' (Bourdieu's, 2001) on institutions which is then imposed on the faculty. Of course, the faculty seem to play a central role in translating this top-down approach to policy by introducing alternative components into their MA programmes that not only address students' needs but also meet universities' financial targets. 
With regard to the second research question, while a great majority of the UK participants regarded the MA dissertation integral to MA TESOL programmes, most US participants believed otherwise. We would argue that these various assumptions not only illustrate norms, expectations and epistemological orientations of the academic communities of practice in question, but they also highlight socio-political factors that lead to these various assumptions. In the UK, the MA component is generally compulsory while in the USA, many MA TESOL programmes do not have a dissertation component. In Australia, it seems that dissertations are reserved for high achievers.

Informed by Bourdieusian frameworks, the academic literacies approach can explain why a particular literacy, the MA dissertation in this case, is absent or present in comparable educational contexts. It seems that a mobile market of students has led to more student intakes and resulted in more institutional pressure on faculty and academic departments to address these developments by promoting non-dissertation programmes. Bourdieu's concepts of cultural capital is particularly useful and relevant to our discussion (Grenfell \& James, 1998, p. 21). He regards cultural capital as "the product of education" or "an 'academic market', which can be connected to "individuals in their general educated character-accent, dispositions, learning, etc.; connected to objects— books, qualifications, machines, dictionaries, etc.; and connected to institutions - places of learning, universities, libraries, etc.” (Grenfell \& James, 1998, p. 21). Having worked in non-Anglophone contexts, it seems to us that a powerful cultural capital in various non-Anglophone countries appears to be an academic degree obtained in an Anglophone country, which explains why many international students strive to study in Anglophone countries. In the meantime, it seems that tuition fees from seemingly dropping home students in Anglophone countries do not suffice to cover the rising costs of running these institutions, 
pushing them to rely on higher tuition fees from overseas students. This might indicate that "these programs are responding to market forces" (Stapleton \& Shao, 2018) to drop the dissertation from MA programmes for three main reasons. First, non-dissertation track MA TESOL programmes are more appealing to overseas students who need a terminal degree from an Anglophone country regardless of the presence or absence of a dissertation component. Secondly, since overseas students seem to be generally less proficient in academic writing, the absence of dissertation is appealing as the faculty will not need to go through the laborious task of providing feedback on various drafts of the dissertation. Finally, the absence of the MA dissertation will boost intake as it shortens the MA programmes, which is in line with institutions' desire to generate more income through higher tuition fees of overseas students. These forces, therefore, provide symbolic violence to restructure MA programmes.

Two other Bourdieusian concepts are quite relevant here: 'field', the objective realities in the social world, and 'habitus', the customized subjective reproductions of those realities by social agents. It seems that market forces, e.g. attending to students' needs, have created 'fields of objective structures' that are acted out and realized differently across the five countries, i.e. creating various 'habituses' across the five countries. What is interesting, though, is that Bourdieu's concept of 'habitus' primarily revolves around 'individuals' while what we have observed is indicative of a 'collective habitus' to indicate how 'market fields' are realized in 'institutional habituses' across various countries. In this case, market forces, such as the drive to cater for the varied needs of international and domestic students, seem to be affecting institutional policies and are also affected by them. As we have seen, the 'market field' includes a focus on students needs, competition to intake more students, and the need to ensure fast and efficient graduation. These objective 'market field' structures work in a dynamic interplay with 
local realities including faculty assumptions regarding MA programmes and the particular institutional pressures which have led to the various practices and conceptions identified in this study. Last but not least, the academic literacies tradition can be informed by Bourdeusian theories to help us understand not only the cultural contexts of text production but also the sociopolitical factors affecting the presence or absence of certain academic practices and texts.

\section{References}

Agar, M. (1996). The professional stranger: An informal introduction to ethnography. San Diego, CA: Academic Press.

Allison, D., Cooley, L., Lewkowics, J., \& Nunad, D. (1998). Dissertation writing in action: The development of a dissertation writing support program for ESL graduate research students. English for Specific Purposes, 17(2), 199-217.

Barton, D., Hamilton, M., \& Ivanic, R. (1998). Situated literacies: reading and writing in context. London and New York: Routledge.

Becher, T. (1989). Academic tribes and territories: Intellectual enquiry and the cultures of disciplines. Bristol: Open University Press.

Belcher, D. (1994). The apprenticeship approach to advanced academic literacy: Graduate students and their mentors. English for Specific Purposes, 13(1), 23-34.

Belcher, D., \& Hirvela, A. (2005). Writing the qualitative dissertation: What motivates and sustains commitment to a fuzzy genre? Journal of English for Academic Purposes, 4, 187-205.

Bourdieu, P. (1991). Language and symbolic power (G. Raymond \& M. Adamson, Trans.). Cambridge, England: Polity Press. 
Bourdieu, P. (2001). Masculine domination (R. Nice, Trans.). Stanford, CA: Stanford University Press.

Canagarajah, A. S. (1996). “Nondiscursive'” requirements in academic publishing: Material resources of periphery scholars, and the politics of knowledge production. Written Communication, 13, 435-472.

Casanave, C. P. (2003). Looking ahead to more sociopolitically-oriented case study research in L2 writing scholarship: (But should it be called "post-process"?). Journal of Second Language Writing, 12, 85-102.

Dong, Y. (1996). Learning how to use citations for knowledge transformation: Non-native doctoral students' dissertation writing in science. Research in the Teaching of English, 30, 428-457.

Dysthe, O. (2002). Professors as mediators of academic text cultures: An interview study with advisors and master's degree students in three disciplines in a Norwegian university. Written Communication, 19(4), 493-544.

Freebody, P., \& Luke, A. (1990). 'Literacies' programs: debates and demands in cultural context. Prospect, 5(3), 7-16.

Freire, P. (1970). Cultural action for freedom. Cambridge: Harvard Educational Review.

Gee, J. P. (2015). Social linguistics and literacies: Ideology in discourses ( $5^{\text {th }}$ Ed.). London and New York: Routledge.

Grenfell, M., \& James, D. (1998). Bourdieu and Education. London: Falmer Press. (pp. 7-26).

Glaser, B. G. (1992). Basics of grounded theory analysis. Mill Valley, CA: Sociology Press. 
Hasrati, M.( 2013a). Material and credentialing incentives as symbolic violence: Local engagement and global participation through joint publication. Journal of Business and Technical Communication, 27(2), 154-179.

Hasrati, M. (2013b). Why bother about writing a Master's dissertation: Assumptions of faculty and Master's students in an Iranian setting. Asia Pacific Education Review, 14(3), 455465.

Hasrati, M., \& Tavakoli, P. (2015). Globalisation and MA TESOL programmes in the UK. Higher Education, 69(4), 547-565.

Holbrooke, A., Bourke, S., Lovat, T. \& Fairbaim, H. (2008). Consistency and inconsistencies in $\mathrm{PhD}$ thesis examination. Australian Journal of Education, 52(1), 36-48.

Jenkins, S., Jordan, M. K., \& Weiland, P. O. (1993). The role of writing in the graduate engineering education: a survey of faculty beliefs and practices. English for Specific Purposes, 12, 51-67.

Kiley, M. \& Mullins, G. (2004). Examining the examiner: how inexperienced examiners approach the assessment of research theses. International Journal of Educational Research, 41, 121-135.

Lillis, T., \& Curry, M.J. (2010). Academic writing in a global context: The politics and practices of publishing in English. London, England: Routledge.

Lindsay, S. (2015). What works for doctoral students in completing their thesis? Teaching in Higher Education, 20(2), 183-196.

Mitchell, C. (1984). Case studies. In R. Ellen (Ed.), Ethnographic research: a guide to general conduct (pp. 237-241). London, England: Academic Press. 
Nightingale, P. (1984). Examination of research theses. Higher Education Research and Development, 3(2), 137-150.

Ohashi, J., Ohashi, H., \& Paltridge, B. (2008). Finishing the dissertation while on tenure track: Enlisting support from inside and outside the academy. In C. Casanave, X. Li (Eds.), Learning the literacy practices of graduate school: Insiders reflections on academic enculturation, (pp. 218-229). Ann Arbor, USA: University of Michigan Press.

Paltridge, B. (2002). Thesis and dissertations writing: An examination of published advice and actual practice. English for Specific Purposes, 21(2), 125-143.

Powers, J. (1994). What faculty say about working with graduate ESL Writers. Paper presented at the Annual Meeting of Teaching English as a Second Language, Baltimore, MD, March, 1994.

Sinkonvic, R., Richardson, C., \& Lew, Y. (2016). Enhancing student competency and employability in international business through master's dissertations. Journal of Teaching in International Business, 26(4), 293-317.

Stapleton, P., \& Shao, Q. (2018). A worldwide survey of MATESOL programs in 2014: Patterns and perspectives. Language Teaching Research, 22(1), 10-28.

Stracke, E., \& Kumar, V. (2010). Feedback and self-regulated learning: insights from supervisors' and PhD examiners' reports. Reflective Practice, 11(1), 19-32.

Street, B. (1984). Literacy in theory and practice. Cambridge. Cambridge University Press.

Tinkler, P. \& Jackson, C. (2000). Examining the doctorate: institutional policy and the PhD examination process in Britain. Studies in Higher Education, 25(2), 167-180.

Wallerstein, I. (1974). The rise and future demise of the world capitalist system: concepts for comparative analysis. Comparative Studies in Society and History, 16(4), 387-415. 
Webb, J., Schirato, T., \& Danaher, G. (2002). Understanding Bourdieu. Crows Nest, NSW:

Allen \& Unwin.

Appendix

$\underline{\text { Section One }}$

Please embolden or change the color of your answer.

1. MA Applied Linguistics programs have been/are being modified to accommodate for the increasing number of non-native students.

\begin{tabular}{|l|l|l|l|l}
\hline strongly agree & agree & I am not sure & disagree & $\begin{array}{l}\text { strongly } \\
\text { disagree }\end{array}$ \\
\hline
\end{tabular}

2. The MA thesis component is not a necessary component in MA programs.

\begin{tabular}{|l|l|l|l|l|}
\hline strongly agree & agree & I am not sure & disagree & $\begin{array}{l}\text { strongly } \\
\text { disagree }\end{array}$ \\
\hline
\end{tabular}

3. The MA thesis is being dropped from MA programs in response to market driven factors.

\begin{tabular}{|l|l|l|l|l|}
\hline strongly agree & agree & I am not sure & disagree & $\begin{array}{l}\text { strongly } \\
\text { disagree }\end{array}$ \\
\hline
\end{tabular}

4. The non-dissertation track programs include components that are as effective as the MA thesis in helping students grow professionally.

\begin{tabular}{|l|l|l|l|l|}
\hline strongly agree & agree & I am not sure & Disagree & $\begin{array}{l}\text { strongly } \\
\text { disagree }\end{array}$ \\
\hline
\end{tabular}

5. MA theses are important in helping students learn disciplinary world views.

\begin{tabular}{|l|l|l|l|l|}
\hline strongly agree & agree & I am not sure & disagree & $\begin{array}{l}\text { strongly } \\
\text { disagree }\end{array}$ \\
\hline
\end{tabular}

6. MA theses are important in helping students learn disciplinary writing conventions. 


\begin{tabular}{|l|l|l|l|l|}
\hline strongly agree & Agree & I am not sure & disagree & $\begin{array}{l}\text { strongly } \\
\text { disagree }\end{array}$ \\
\hline
\end{tabular}

7. The main purpose of writing an MA thesis is to get familiar with research.

\begin{tabular}{|l|l|l|l|l|}
\hline strongly agree & Agree & I am not sure & disagree & $\begin{array}{l}\text { strongly } \\
\text { disagree }\end{array}$ \\
\hline
\end{tabular}

8. Non-thesis track MA Applied Linguistics programs are equally valuable as thesis track ones.

\begin{tabular}{|l|l|l|l|l|}
\hline strongly agree & Agree & I am not sure & disagree & $\begin{array}{l}\text { strongly } \\
\text { disagree }\end{array}$ \\
\hline
\end{tabular}

9. I would have no hesitation accepting a non-thesis track MA Applied Linguistics graduate to a $\mathrm{PhD}$ program.

\begin{tabular}{|l|l|l|l|l|}
\hline strongly agree & Agree & I am not sure & disagree & $\begin{array}{l}\text { strongly } \\
\text { disagree }\end{array}$ \\
\hline
\end{tabular}

10. Thesis-track programs are more suitable for students who want to continue into a PhD.

\begin{tabular}{|l|l|l|l|l|}
\hline strongly agree & Agree & I am not sure & Disagree & $\begin{array}{l}\text { strongly } \\
\text { disagree }\end{array}$ \\
\hline
\end{tabular}

Please complete the following sentence:

11. Non-thesis track MA Applied Linguistics programs are becoming widespread because ....

If you have any other comments, please write in the space below.

12. In my university, admission requirements for new MA Applied Linguistics students have become less strict with regard to ...

a. Student English language proficiency.

\begin{tabular}{|l|l|l|l|l|}
\hline strongly agree & agree & I am not sure & Disagree & $\begin{array}{l}\text { strongly } \\
\text { disagree }\end{array}$ \\
\hline
\end{tabular}


b. Student previous disciplinary knowledge.

\begin{tabular}{|c|c|c|c|c|}
\hline strongly agree & agree & I am not sure & Disagree & $\begin{array}{l}\text { strongly } \\
\text { disagree }\end{array}$ \\
\hline \multicolumn{5}{|c|}{ c. Student experience and skills. } \\
\hline strongly agree & agree & I am not sure & Disagree & $\begin{array}{l}\text { strongly } \\
\text { disagree }\end{array}$ \\
\hline
\end{tabular}

13. MA Applied Linguistics has been/is being modified to recruit from new student markets.

\begin{tabular}{|l|l|l|l|l|}
\hline strongly agree & agree & I am not sure & Disagree & $\begin{array}{l}\text { strongly } \\
\text { disagree }\end{array}$ \\
\hline
\end{tabular}

14. MA Applied Linguistics programs have become less theoretically focused.

\begin{tabular}{|l|l|l|l|l|}
\hline strongly agree & agree & I am not sure & Disagree & $\begin{array}{l}\text { strongly } \\
\text { disagree }\end{array}$ \\
\hline
\end{tabular}

If you have any other comments, please write in the space below.

15. In recent years, MA programs put more emphasis on ...

a. research training.

\begin{tabular}{|l|l|l|l|l|}
\hline strongly agree & agree & I am not sure & Disagree & $\begin{array}{l}\text { strongly } \\
\text { disagree }\end{array}$ \\
\hline
\end{tabular}

b. professional development.

\begin{tabular}{|c|c|c|c|c|}
\hline strongly agree & agree & I am not sure & Disagree & $\begin{array}{l}\text { strongly } \\
\text { disagree }\end{array}$ \\
\hline \multicolumn{5}{|c|}{ c. classroom-based and action research } \\
\hline strongly agree & agree & I am not sure & Disagree & $\begin{array}{l}\text { strongly } \\
\text { disagree }\end{array}$ \\
\hline
\end{tabular}

16. Over the past years, institutional policies push for ...

a. faster graduation processes. 


\begin{tabular}{|l|l|l|}
\hline yes & no & I am not sure \\
\hline
\end{tabular}

b. more admissions on MA programs.

\begin{tabular}{|l|l|l|}
\hline yes & no & I am not sure \\
\hline
\end{tabular}

c. new pathways to substitute MA theses.

\begin{tabular}{|l|l|l|}
\hline yes & no & I am not sure \\
\hline
\end{tabular}

17. Does your MA Applied Linguistics have a thesis component? If yes, please answer this question. If no, please skip this questions and go to Section Two.

Thinking of MA Applied Linguistics students, how do you rate the importance of the following as a main aim of a Master's thesis?

a. Developing skills in research methodology

\begin{tabular}{|l|l|l|l|}
\hline $\begin{array}{l}\text { very } \\
\text { important }\end{array}$ & important & $\begin{array}{l}\text { somewhat } \\
\text { important }\end{array}$ & not important \\
\hline
\end{tabular}

b. Developing knowledge in a disciplinary area

\begin{tabular}{|l|l|l|l|}
\hline $\begin{array}{l}\text { very } \\
\text { important }\end{array}$ & important & $\begin{array}{l}\text { somewhat } \\
\text { important }\end{array}$ & not important \\
\hline
\end{tabular}

c. Contributing to knowledge

\begin{tabular}{|l|l|l|l|}
\hline $\begin{array}{l}\text { very } \\
\text { important }\end{array}$ & important & $\begin{array}{l}\text { somewhat } \\
\text { important }\end{array}$ & not important \\
\hline
\end{tabular}

d. Learning to write a long piece of academic prose

\begin{tabular}{|l|l|l|l|}
\hline $\begin{array}{l}\text { very } \\
\text { important }\end{array}$ & important & $\begin{array}{l}\text { somewhat } \\
\text { important }\end{array}$ & not important \\
\hline
\end{tabular}

e. Becoming a professional teacher

\begin{tabular}{|l|l|l|l|}
\hline $\begin{array}{l}\text { very } \\
\text { important }\end{array}$ & important & $\begin{array}{l}\text { somewhat } \\
\text { important }\end{array}$ & not important \\
\hline
\end{tabular}

f. Researching an original topic

\begin{tabular}{|l|l|l|l|}
\hline $\begin{array}{l}\text { very } \\
\text { important }\end{array}$ & important & $\begin{array}{l}\text { somewhat } \\
\text { important }\end{array}$ & not important \\
\hline
\end{tabular}

g. Becoming a researcher

\begin{tabular}{|l|l|l|l|}
\hline $\begin{array}{l}\text { very } \\
\text { important }\end{array}$ & important & $\begin{array}{l}\text { somewhat } \\
\text { important }\end{array}$ & not important \\
\hline
\end{tabular}

h. Taking a research approach to teaching

\begin{tabular}{|l|l|l|l|}
\hline $\begin{array}{l}\text { very } \\
\text { important }\end{array}$ & important & $\begin{array}{l}\text { somewhat } \\
\text { important }\end{array}$ & not important \\
\hline
\end{tabular}


i. Publishing the findings

\begin{tabular}{|l|l|l|l|}
\hline $\begin{array}{l}\text { very } \\
\text { important }\end{array}$ & important & $\begin{array}{l}\text { somewhat } \\
\text { important }\end{array}$ & not important \\
\hline
\end{tabular}

If you have any other comments, please write in the space below

\section{$\underline{\text { Section Two }}$}

Please answer the following questions in as much detail as you wish.

1. In your opinion, do you think MA Applied Linguistics programs are changing or have changed over the past 10-15 years? If yes, how?

2. What do you think are the causes of these changes, if any?

3. How do non-thesis track programs compensate for learning that could have achieved through writing a thesis?

\section{$\underline{\text { Section Three }}$}

Please answer the following questions about your experience on MA Applied Linguistics programs.

1. How many years have you been teaching in MA Applied Linguistics programs?

2. How many years have you been supervising MA Applied Linguistics theses?

3. How many MA Applied Linguistics theses have you supervised? 